\title{
THE SIGNIFICANCE OF EUROPEAN UNION FUNDS FOR THE DEVELOPMENT OF THE REGIONS OF EASTERN POLAND
}

\author{
Teresa MIŚ \\ University of Rzeszow, Institute of Economic and Finance, Rzeszow; tmis@ur.edu.pl, \\ ORCID: 0000-0002-5164-0804
}

Purpose: The aim of the article is to evaluate the significance of European Union funds for the development of the regions of Eastern Poland, by focusing on the benefits of obtaining this type of financial support

Design/methodology/approach: When collecting empirical material for the article, the method of economic and general statistics was used. The time range of the research covers the years 2004-2018. The rationale for the location of the research is the peripheral location of Eastern Poland voivodeships and the related problems of low growth and economic development, low population density, and low income of local governments and residents. Moreover, this part of Poland benefits from a special European Union Program that financially supports the development of the researched regions.

Findings: The research has showed that all voivodships of Eastern Poland narrowed their distance to the national average as it was there that the influence of the cohesion policy on the pace of development was the strongest.

Originality/value: The article presents the use of European Union funds, supporting the cohesion policy implemented by local governments in Eastern Poland and the effects of support based on selected indicators, including the absorption rate developed by the present author.

Keywords: EU funds, cohesion policy, regional development, Eastern Poland.

Category of the paper: Research paper.

\section{Introduction}

Poland's accession to the structures of the European Union made it possible to use European funds, which, in practice, allows an increase in economic and social cohesion in the European Union. Thanks to the requirement of taking into account the priorities of the European Union in the field of cohesion policy by regional and local communities that utilise European funds, it may be expected that at the regional and local level, goals related to global problems, 
including low-emission economy, preventing climate change, reducing poverty, etc., will be achieved (Czudec et al., 2018; Holden et al., 2017; Lugo-Morin, 2016). The use of EU funds has given many regions ample investment opportunities that significantly boost economic growth. Skilful use of these funds allows the region to release its economic potential, which is a source of sustainable development. The use of funds is a challenge for both the units responsible for implementing the programs and their recipients. The attitudes and knowledge of these entities constitute the potential necessary to achieve success in the development of a given region (Katoła, 2012; Miś, 2008).

One of the priorities of the European Union's cohesion policy is such support for development that should lead to reducing the differences in the level of development and living standards in the regions of the EU. The effect of this policy is to increase the competitiveness of regional and local economy. The territorial approach in the process of improving cohesion, understood as geographical space, has been increasingly emphasized (Lambregts et al., 2008; Miś, and Zając, 2020).

Accession to the EU entails the obligation to conduct regional policy, but at the same time complicates the management of economic policy. The new regional policy is not only redistribution, but also allocation, which enables weak regions to increase their competitiveness and growth potential and to promote sustainable development by maintaining a high level of initiatives on a micro scale, e.g. supporting the development of small and medium-sized enterprises, as well as on a macro scale (stabilization processes, coordination of public policies and decentralization) (Pietrzyk, 2005).

Financial capital from EU funds allows regions, characterized by certain inconveniences and development deficiencies in the economy, to match the standards imposed by the European Union (Oręziak, 2006). Acquisition and proper allocation of European Union funds is of fundamental importance in improving the competitiveness of peripheral regions that are lagging behind in development, i.e. such as Eastern Poland (Sieradzka, 2012). In this context, it may be justified to undertake research on the evaluation of the use of EU funds in the regions of Eastern Poland.

\section{Methods}

The empirical material used in the research concerns five voivodships of Eastern Poland, i.e. Lubelskie, Podkarpackie, Podlaskie, Świętokrzyskie and Warmińsko-Mazurskie. The figures are derived from the Ministry of Investment and Economic Development and Statistics Poland (GUS) in Warsaw. The time scope of the research covers the years 2004-2018 and concerns mainly indicators used to assess the level of socio-economic development. Data on European Union funds obtained by local governments in Eastern Poland as part of the 
implementation of the cohesion policy concern the years 2007-2018 (programming periods 2007-2013 and 2014-2020). The collected and structured empirical material was developed in tabular and graphical form, by using the descriptive and comparative analysis methods.

The study of the use of European Union funds by local governments in Eastern Poland is justified by the fact that, apart from their biggest impact on socio-economic changes at the regional and local level, they are a significant beneficiary of these funds since in the years 2007-2013, about 25\% of the total amount of European funds in Poland went to local government units, and in the years 2014-2020 their participation will increase in this respect to 40\% (Hamryszczak, 2016).

In the case of assessing the use of EU funds by local governments of Eastern Poland within the implementation of the cohesion policy, the following indicators were used:

- GDP per capita to assess the level of regional development (this is the basic indicator taken into account by the European Commission when assessing the socio-economic situation of the region and the possible need for funding);

- the amount of European Union funds per capita (in PLN);

- percentage of contracts signed under ROP (Regional Operational Program) 2014-2020;

- percentage of use of individual operational programs;

- absorption rate.

The substantive part of the article presents the results of research illustrating changes in the Gross Domestic Product per capita in Eastern Poland starting from the year of Poland's accession to the European Union, as well as the scale of use of European Union funds supporting the cohesion policy by local governments in Eastern Poland. Attention was also paid to the Regional Operational Program, which was presented graphically to highlight the regions of Eastern Poland against the background of other regions in the country. Then the results of research on the absorption rate and the benefits of using European Union funds by local governments in Eastern Poland are presented.

\section{Results}

Eastern Poland is a region with poorer economic development, consisting mainly of rural areas with a high share of agriculture in the structure of the economy. In the regions of Eastern Poland, rural areas cover $94,758 \mathrm{~km}^{2}$, which constitutes $32.5 \%$ of the total rural areas in Poland. These are regions located in the border area, adjacent to Belarus, Lithuania, Russia, Slovakia and Ukraine. They are characterized by a low quality of human capital, a low level of infrastructure development, limited territorial accessibility and a low level of income of the population and local government units. Therefore, these are voivodships that meet the definition criteria used for peripheral areas (Grosse, 2007; Rosner, 2008; Grzebyk et al., 2013, Balińska, 
2015). Regions of Eastern Poland, however, are characterized by a large environmental and ecological potential, favorable natural and landscape conditions, which is conducive to multifunctional development. In the future, the border location of the Eastern Poland region should be used as an opportunity to establish economic contacts and create cooperation networks, which is a highly preferable phenomenon in the EU's structural policy for 2014-2020. It was also important in programming 2007-2013, which is why in 2007 a special program of the European Union for Eastern Poland was launched (Operational Program: Development of Eastern Poland), which is also continued now as the Operational Program Eastern Poland. It should be added that the voivodships of Eastern Poland also utilize financial resources under other programs supporting the cohesion policy of the European Union. Investments implemented in a given region open up the prospect of positive changes and increasing the region's potential. A skillful use of European Union funds for investments might allow the region to release its economic potential, which is a source of further development. Co-financing from European Union funds allows regions that are characterized by development difficulties to match the standards that exist in developed regions. When implementing projects to improve infrastructure, local authorities treat them as the most important and the most valuable for the broadly understood development. Among the European Union programs that improved the quality of life of the inhabitants of Eastern Poland in 2007-2013, the following ones should be mentioned: Operational Program: Development of Eastern Poland, Regional Operational Programs, Innovative Economy Operational Program, Infrastructure and Environment Operational Program and Human Capital Operational Program and in the years 2014-2020: Eastern Poland Operational Program, Regional Operational Programs, Smart Growth Operational Program, Infrastructure and Environment Operational Program, Knowledge Education Development Operational Program and Digital Poland Operational Program. These programs take into account the improvement of the quality of life through investments in modern technical and social infrastructure as well as in human and social capital.

One of the most important criteria adopted for the classification of particular voivodeships in Poland in terms of the level of development and the related possibility of obtaining funds from the European Union under the cohesion policy is Gross Domestic Product per capita. Table 1 shows the changes in the Gross Domestic Product per capita in Eastern Poland in 20042018, i.e. from the year of Poland's accession to the European Union. The importance of Eastern Poland in generating the Gross Domestic Product (GDP) is lower, as it did not exceed the total GDP of Poland in any of the voivodships. However, it should be noted that Poland's accession to the European Union had a significant impact on improving the situation in the country in terms of this indicator. In each of the voivodships of Eastern Poland, the value of the Gross Domestic Product per capita has increased more than twice over fourteen years, which is an extremely positive phenomenon. It should be added that there are some differences in terms of the value of this indicator between individual voivodeships, with the highest being in the Świętokrzyskie Voivodeship and the lowest in the Lubelskie Voivodeship (Table 1). As mentioned above, in none of the voivodships of Eastern Poland, the value of this indicator 
exceeded the average value for the country, which confirms that all voivodships of Eastern Poland should receive co-financing from the European Union funds under the cohesion policy.

Table 1.

Gross Domestic Product per capita in Poland in Eastern Poland as compared to the rest of the country in the years 2004-2018.

\begin{tabular}{|c|c|c|c|}
\hline \multirow[b]{2}{*}{ Specification } & \multicolumn{3}{|c|}{ Gross Domestic Product per capita (in PLN) } \\
\hline & 2004 & 2018 & $\begin{array}{c}\text { Dynamics, } \\
\text { year } 2004=100\end{array}$ \\
\hline Poland & 24438 & 55066 & 225,3 \\
\hline $\begin{array}{l}\text { Eastern Poland, including } \\
\text { the following voivodeships: }\end{array}$ & 18202 & 38543 & 211,8 \\
\hline Lubelskie & 17302 & 37100 & 214,4 \\
\hline Podkarpackie & 17756 & 38872 & 218,9 \\
\hline Podlaskie & 18019 & 39160 & 217,3 \\
\hline Świętokrzyskie & 19445 & 39742 & 204,4 \\
\hline Warmińsko-Mazurskie & 18490 & 37843 & 204,7 \\
\hline
\end{tabular}

Source: own elaboration on the basis of the data from Statistics Poland in Warsaw.

For Eastern Poland, the cohesion policy is a unique opportunity for development, because its priorities in the new financial perspective 2014-2020 are: smart growth, sustainable development and development which favors social inclusion. The data in Table 2 shows that the local governments of Eastern Poland obtained slightly more funds per capita under the implementation of the European Union's cohesion policy compared to the entire country, which this applies both to the years 2007-2013 and 2014-2018. In the programming period 2007-2013, the highest amount of support per capita was granted to self-governments of the Warmińsko-Mazurskie and Podkarpackie voivodeships, and the lowest to self-governments of the Lubelskie and Świętokrzyskie voivodships. In turn, in the years 2014-2018, the most funds per capita were obtained by local governments of the Warmińsko-Mazurskie Voivodeship. Hence, in the entire analyzed period, i.e. in the years 2007-2018, clearly the most funds per capita under the implementation of the European Union cohesion policy were obtained by the local governments of the Warmińsko-Mazurskie voivodship, and the least by the selfgovernments of the Świętokrzyskie and Lubelskie voivodships (Table 2).

Table 2.

European Union funds per capita obtained by local governments in Eastern Poland within the implementation of coherence policy in the years 2007-2018

\begin{tabular}{|l|r|r|r|}
\hline \multirow{2}{*}{ Specification } & \multicolumn{2}{|c|}{ The amount of EU funds per capita (in PLN) } \\
\cline { 2 - 4 } & $\mathbf{2 0 0 7 - 2 0 1 3}$ & $\mathbf{2 0 1 4 - 2 0 1 8}$ & \multicolumn{2}{c|}{ Total } \\
\hline Poland & 13883 & 9934 & 23817 \\
\hline $\begin{array}{l}\text { Eastern Poland, including } \\
\text { the following voivodeships: }\end{array}$ & 14375 & 9795 & 24170 \\
\hline Lubelskie & 12201 & 9465 & 21666 \\
\hline Podkarpackie & 16202 & 8788 & 24990 \\
\hline Podlaskie & 14686 & 9176 & 23862 \\
\hline Świętokrzyskie & 12424 & 9095 & 21519 \\
\hline Warmińsko-Mazurskie & 16361 & 12453 & 28814 \\
\hline
\end{tabular}

Source: own elaboration on the basis of the data from the Ministry of Investment and Economic Development. 
Table 3 shows the percentage of the use of operational programs in Eastern Poland in 2014-2018. It shows that the most funds were obtained under the Regional Operational Program (ROP). The exception is the Warmińsko-Mazurskie voivodship, where the most funds were obtained under the Infrastructure and Environment Operational Program - even more than the average in Poland. In the case of the Operational Program Eastern Poland, Podlaskie voivodship obtained the most funds. According to the data of the Ministry of Investment and Economic Development, the largest amount of EU money for 2014-2020 has been allocated to transport projects, including road projects $-64 \%$, then to projects in the field of environmental protection, to actions supporting employment and promotion of employee mobility, and to research and development projects (approximately 10\% of the contracted EU funds, respectively).

\section{Table 3}

European funds obtained by local governments in Eastern Poland within the implementation of coherence policy as compared to the rest of the country in the years 2014-2018, divided into operational programs

\begin{tabular}{|c|c|c|c|c|c|c|c|}
\hline \multirow[b]{2}{*}{ Specification } & \multirow[b]{2}{*}{$\begin{array}{c}\text { The } \\
\text { amount } \\
\text { of } \\
\text { obtained } \\
\text { funds } \\
\text { (PLN } \\
\text { million) }\end{array}$} & \multicolumn{6}{|c|}{ Operational Programs (w \%) } \\
\hline & & $\begin{array}{c}\text { OP } \\
\text { Infra- } \\
\text { struc- } \\
\text { ture and } \\
\text { Environ- } \\
\text { ment }\end{array}$ & $\begin{array}{c}\text { OP } \\
\text { Smart } \\
\text { Growth }\end{array}$ & $\begin{array}{c}\text { OP } \\
\text { Knowledge } \\
\text { Education } \\
\text { Development }\end{array}$ & $\begin{array}{c}\text { OP } \\
\text { Eastern } \\
\text { Poland }\end{array}$ & $\begin{array}{c}\text { OP } \\
\text { Digital } \\
\text { Poland }\end{array}$ & $\begin{array}{c}\text { ROP } \\
\text { Regional } \\
\text { Operational } \\
\text { Program }\end{array}$ \\
\hline Poland & 381750,8 & 44,6 & 11,4 & 4,0 & 2,4 & 3,0 & 33,7 \\
\hline $\begin{array}{l}\text { Eastern Poland, } \\
\text { including the } \\
\text { following } \\
\text { voivodeships: }\end{array}$ & 15823,6 & 29,0 & 10,6 & 2,4 & 12,3 & 2,8 & 42,3 \\
\hline Lubelskie & 20215,6 & 27,5 & 10,3 & 2,4 & 9,1 & 5,5 & 44,7 \\
\hline Podkarpackie & 18689,6 & 24,1 & 15,7 & 2,7 & 9,1 & 2,3 & 45,0 \\
\hline Podlaskie & 10897,2 & 21,7 & 10,3 & 2,2 & 21,6 & 1,5 & 42,0 \\
\hline Świętokrzyskie & 11410,1 & 27,0 & 9,2 & 3,1 & 11,5 & 3,1 & 46,0 \\
\hline $\begin{array}{l}\text { Warmińsko- } \\
\text { Mazurskie }\end{array}$ & 17905,5 & 44,9 & 7,5 & 1,5 & 10,1 & 1,4 & 34,6 \\
\hline
\end{tabular}

Source: own elaboration on the basis of the data from the Ministry of Investment and Economic Development (as of the end of December 2018).

Due to the fact that the voivodships of Eastern Poland financed their investments from ROPs to the largest extent (more than on a national scale), Map 1 shows the percentage of contracts signed not only in Eastern Poland but in all regions in the country. Most projects under the ROP were implemented in the Pomorskie Voivodeship. The Opolskie, Wielkopolskie and Mazowieckie voivodships also perform very well: the value of EU funds in the signed contracts reaches $74-78 \%$ there. The fewest ROP projects were implemented in Zachodniopomorskie and Kujawsko-Pomorskie. In the regions of Eastern Poland, most contracts were signed in Lubelskie and Podkarpackie. The areas of co-financing under the ROP (where the expenditure ranges from 30 to $32 \%$ of the available allocation) are as follows: employment, support for SME development, education and development of transport infrastructure. The indicator presented in figure 1 is very important because it shows the activity of voivodship self- 
governments in obtaining funding, which until now was at a low level. Moreover, projects implemented under all 16 regional programs have a value of 131.6 billion PLN, including 90.1 billion PLN from the EU. The largest pool of EU money (76 billion PLN, i.e. $32 \%$ of the value of signed contracts) was obtained to support sustainable transport. Significant amounts were also involved in the implementation of investments promoting the transition to a lowcarbon economy (32 billion PLN, i.e. 13\% of the value of contracts signed), as well as in strengthening the area of the research and development and the development of innovation (22 billion PLN, i.e. 9\% of the value of contracts).

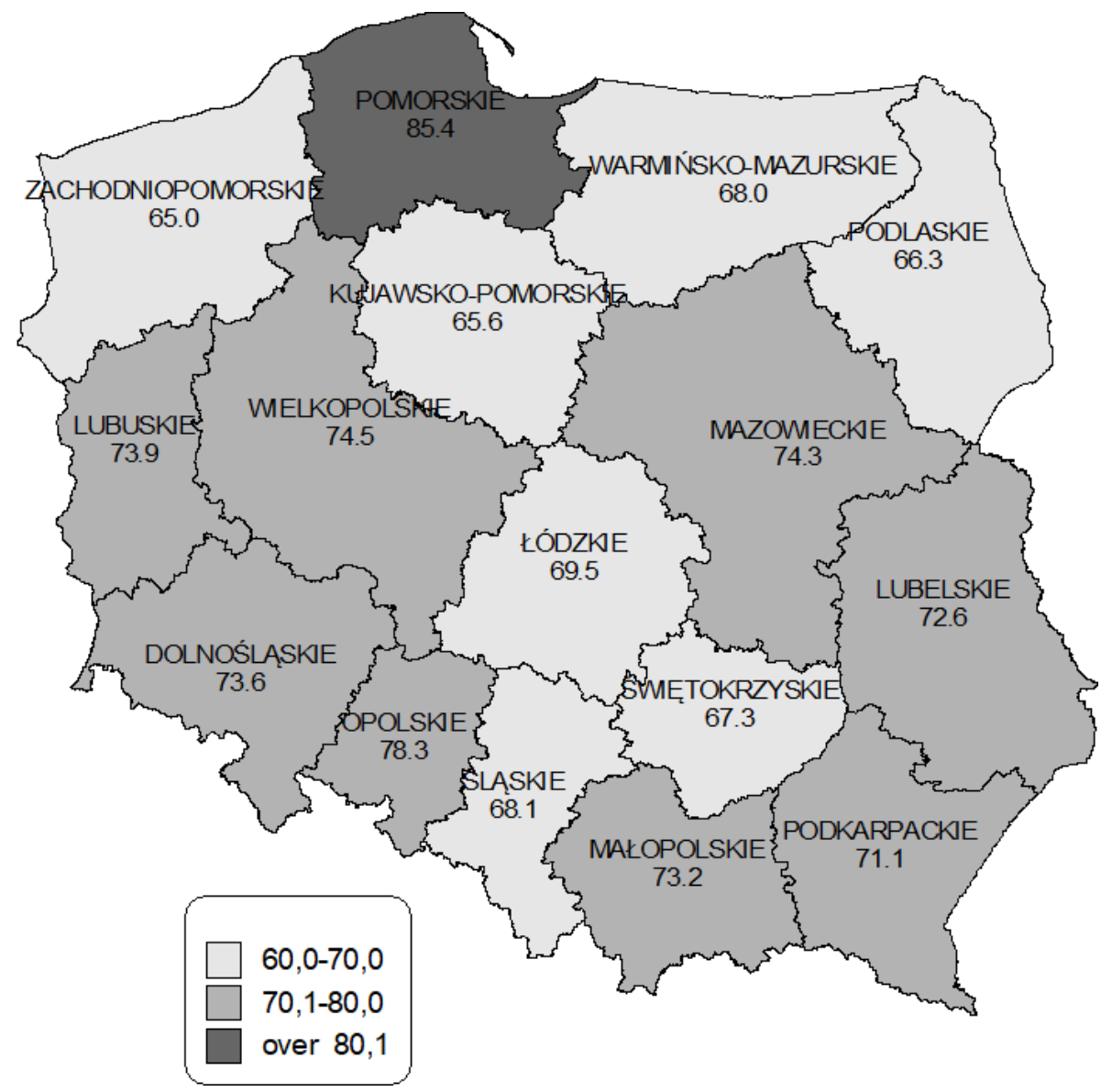

Figure 1. The level of utilisation of funds within ROP 2014-2020, signed contracts (in \%). Source: own elaboration on the basis of the data from the Ministry of Investment and Economic Development

The implementation of the European Union development policy, including the regional policy, is subject to systematic evolution towards more and more effective and efficient models, taking into account the advancement of pro-efficiency solutions based on the paradigm of sustainable development, as the most comprehensive approach to development. A similar evolution proceeds also with respect to indicators, models for the analysis and evaluation of the effectiveness of public programs and policies, which gain new dimensions, contexts and methods of evaluating the regional development policy (Malik, 2011).

The article proposes an indirect measure of the value added generated by EU funds, which is the absorption rate. This indicator shows the actual share of individual regions of Eastern Poland in the absorption of financial resources in the amount of support in relation to the total 
resources of the entire region (5 voivodeships in total). They indicate the involvement of local governments in obtaining funds for the implementation of activities related to the improvement of the quality of life of residents, i.e. initiatives undertaken to mobilize endogenous human and natural resources, infrastructure, social, environmental, cultural investments, etc. The values of the indicator should be higher than 1. The highest level of absorption of EU funds occurred in the Warmińsko-Mazurskie voivodship. It should be pointed out here that in this voivodship also the lowest value of GDP per capita and the highest amounts of co-financing per capita were found. It is a positive phenomenon and proves that the authorities of this voivodeship influence the improvement of the quality of life of the inhabitants by undertaking initiatives in the field of investments financed under the cohesion policy. A high level of absorption of EU funds is also observed in the Podkarpackie and Podlaskie voivodships (figure 2). Values below 1 mean that the absorption of funds for the improvement of the socio-economic situation is lower than it results from the region's potential. The self-government authorities of the Lubelskie and Świętokrzyskie voivodships must intensify their activity in applying for co-financing of projects from EU funds.

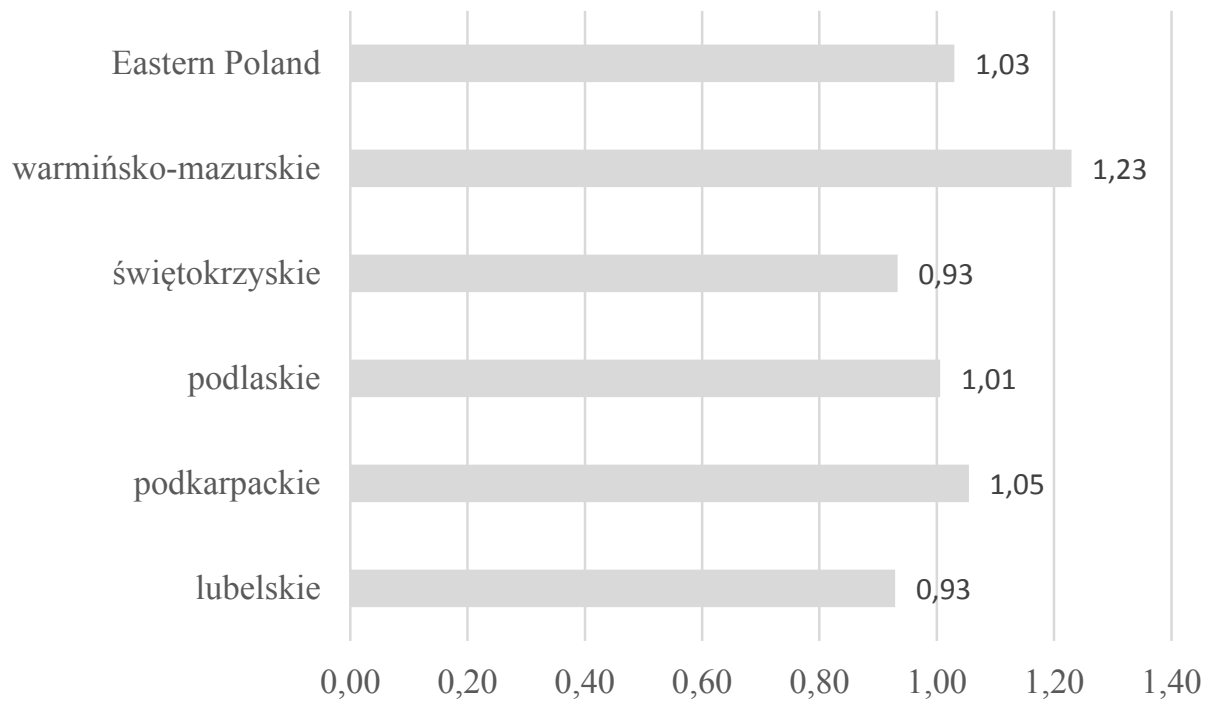

Figure 2. The absorption rate in the regions of Eastern Poland. Source: own calculation.

Investments in the improvement of territorial accessibility, such as construction and modernization of the road, rail and air network, had the largest share in the use of cohesion policy money in Eastern Poland. A significant pool of EU funds was also earmarked for investments in social infrastructure and the development of human capital. Investments which support entrepreneurship, innovation and research and development, as well as environmental projects, including activities in the field of wastewater treatment, air quality improvement, waste management, nature protection or counteracting natural hazards, were ranked next (Biuletyn Informacyjny, 2019). 


\section{Discussion}

New key elements of the reform of the European Union's cohesion policy indicate the need to improve the quality of life by supporting local and regional development, paying particular attention to the role of entrepreneurship and smart specialization (McCann, and Ortega-Argilés, 2016). It was indicated that all voivodeships of Eastern Poland, under smart specializations, should improve the quality of life of the inhabitants by allocating EU funds for activities related to the improvement and development of infrastructure, innovative solutions in every field, including agriculture and rural areas. From the perspective of cohesion policy, these initiatives seem to be of utmost importance.

Thanks to the involvement of European Union funds, the authorities carry out activities aimed at improving infrastructure, and mainly at the expansion of roads, water and sewage networks, or the dynamization of public facilities for the local community through the development of sport, culture and recreation (Sieradzka, 2012). Each country belonging to the structures of the European Union receives invaluable support for its own national economy. This aid concerns areas that absorb money capital and ensures socio-economic growth, technological transformations, modernization and restructuring. Financial capital from EU funds allows regions characterized by certain inconveniences and development deficiencies in the economy to match the standards imposed by the European Union (Oręziak, 2006). The allocation of funds is carried out by confronting the current situation of a given area with the assumptions set out in the regional development strategy, thanks to which it is possible to precisely define the direction of expenditure of the funds. The above mentioned areas also include the voivodships of Eastern Poland, which can benefit from a rational use of funds in local infrastructure, primarily in the construction of communication connections (roads, railways), housing infrastructure and the required sanitary connections. Aid funds are also intended for investments in public utility buildings, such as: community centers, recreation and entertainment centers, parking lots, tourist routes, bicycle paths and playgrounds, as well as sports facilities and cultural centers.

When implementing projects to improve infrastructure, local authorities treat them as having primary significance and utmost importance for broadly understood development. It should be mentioned that the use of funds for the development of technical infrastructural aspects is 'hard' investments of EU financing, and those related to with the socio-cultural aspect are 'soft' investments (Katoła, 2012). In conclusion, it should be stated that the cohesion policy does not guarantee the reduction of disproportions, but stimulates changes for the effective use of endogenous resources and improvement of the quality of life. EU funds are intended to improve indicators used to assess the socio-economic level of regional development. 


\section{Summary}

Poland's accession to the European Union made it possible to use funds under the implementation of the cohesion policy. This, in turn, contributed to, among other things, an increase in the Gross Domestic Product per capita. The research showed that in all voivodeships of Eastern Poland the value of the Gross Domestic Product per capita more than doubled in 2004-2018, i.e. from the year of Poland's accession to the European Union, which seems to be a very positive phenomenon. However, in none of the voivodships of Eastern Poland the value of this indicator exceeded the average value for the country, which means that all these voivodships should still obtain funds from the European Union under the cohesion policy. Hence, in the years 2007-2018 self-governments of Eastern Poland obtained slightly more funds in this area per 1 inhabitant compared to the entire country, with the highest funds obtained by self-governments of the Warmińsko-Mazurskie voivodship, with the lowest GDP per capita in the scale of the entire country (except for the Lubelskie voivodeship). This seems to be confirmed by the analysis of the absorption rate, which has the best values for Warmia and Mazury. This points to the fact that all voivodeships of Eastern Poland narrowed the distance to the national average and it was there that the influence of the Cohesion Policy on the pace of development was the strongest.

\section{References}

1. Balińska, A. (2015). Czynniki rozwoju terenów peryferyjnych Polski Wschodniej. Journal of Agribusiness and Rural Development, 36(2), pp. 153-160.

2. Biuletyn Informacyjny Fundusze Europejskie $w$ Polsce, no. 52/2019. Warszawa: Ministerstwo Inwestycji i Rozwoju.

3. Czudec, A., Majka, A., Zając, D. (2018). Impact of European Union Cohesion Policy at Local Level (Rural Areas of Eastern Poland Case Study). Lex localis - Journal of Local Self-Government, 16(4), pp. 785-803.

4. Grosse, T.G. (2007). Wybrane koncepcje teoretyczne i doświadczenia praktyczne dotyczace rozwoju regionów peryferyjnych, Ekspertyzy do Strategii Rozwoju SpolecznoGospodarczego Polski Wschodniej do roku 2020. Warszawa: Ministerstwo Rozwoju Regionalnego, 119-134.

5. Grzebyk, B., Miś, T., Pyrkosz, D.S. (2014). Changing Trends of the Socio-Economic Development of Rural Areas in Eastern Poland. In: B. Babjakova, A. Bandlerova, D. Brown, A. Kaleta, L.J. Kulcsar, J. Singelmann (Eds.), Social and Economic 
Transformations Affecting Rural People and Communities in Central and Eastern Europe since 1990 (pp. 18-29). Slovakia: Slovak University of Agriculture in Nitra.

6. Hamryszczak, A. (2016). Konieczność efektywnego zainwestowania przez jednostki samorzadu terytorialnego funduszu UE w perspektywie finansowej 2014-2020. Kondycja finansowa jednostek samorządu terytorialnego a możliwości wynikające z perspektywy finansowej 2014-2020. Rzeszów: Regionalna Izba Obrachunkowa w Rzeszowie, Wydział Ekonomii Uniwersytetu Rzeszowskiego.

7. Hardeman, S., Dijkstra, L. (2014). The EU Regional Human Development Index. JRC Scientific and Policy.

8. Heley, J., Jones, L. (2012). Relational rural: Some thoughts on relating things and theory in rural studies. Journal of Rural Studies, 28, pp. 208-217.

9. Holden, E., Linnerud, K., Banister, D. (2017). The Imperatives of Sustainable Development. Sustainable Development, no. 25, pp. 213-226.

10. Katoła, A. (2012). Wpływ wykorzystania funduszy unijnych na wzrost konkurencyjności gmin. Zeszyty Naukowe Uniwersytetu Szczecińskiego. Studia i Prace Wydziału Nauk Ekonomicznych i Zarządzania Uniwersytetu Szczecińskiego, 25, pp. 161-177.

11. Lambregts, B., Janssen-Jansen, L., Haran, N. (2008). Effective governance for competitive region in Europe: the difficult case of the Randstad. GeoJournal, 72, pp. 45-57.

12. Lugo-Morin, D.R. (2016). Dynamics of Rural Communities Under Climate Change. Sustainable Development, 24, pp. 345-356.

13. Malik, K. (2011). Ewaluacja polityki rozwoju regionu: metody, wymiary i konteksty rozwoju zrównoważonego. Studia KPZK PAN, vol. $C X X X V$.

14. McCann, P., Ortega-Argilés, R. (2016). Smart specialisation, entrepreneurship and SMEs: issues and challenges for a results-oriented EU regional policy. Small Business Economics, 46(4), pp. 537-552.

15. Miś, T. (2008). Rola lokalnych instytucji w procesie absorpcji środków unijnych dla rolnictwa w opinii rolników południowo-wschodniej Polski. Wieś i Rolnictwo, no. 3(140), pp. 130-141.

16. Miś, T., Zając, D. (2020). A Results of European Union Cohesion Policy in terms of quality of life improvement on regional level (as exemplified by Eastern Poland). Lex localis Journal of Local Self-Government, Vol. 18, No. 1, pp. 53-69.

17. Oręziak, L. (2006). Finanse Unii Europejskiej. Warszawa: PWN.

18. Pietrzyk, J. (2005). Polityka regionalna. In: Sławiński (ed.), Na ile wejście Polski do Unii Europejskiej ułatwia, a na ile komplikuje prowadzenie polityki gospodarczej? Warszawa: PTE.

19. Rosner, A. (2008). Przestrzenne zróżnicowanie poziomu rozwoju społecznogospodarczego obszarów wiejskich w Polsce. In: M. Drygas, A. Rosner (Eds.), Polska wieś i rolnictwo w Unii Europejskiej, Dylematy i kierunki przemian. Warszawa: IRWiR PAN. 